A R C HIWA, BIBLIOTEK I

I MUZEA KOŚCIELNE 110 (2018)

https://doi.org/10.31743/abmk.2018.110.21

KS. KAZIMIERZ ŚMIGIEL* - GNIEZNO

\title{
Z PROBLEMATYKI BADAWCZEJ DOTYCZĄCEJ DZIEJÓW PRYMASOSTWA POLSKIEGO
}

Badacz dziejów prymasostwa napotyka już na wstępie na brak bezpośrednich materiałów źródłowych, bowiem nie zachowało się archiwum prymasów wytworzone w czasach od XV-XVIII wieku, a przechowywane w Lowiczu. Obejmowało ono 163 tomów akt. W połowie XIX wieku zainteresował się nim arcybiskup warszawski Zygmunt Szczęsny Feliński i polecił je przewieźć do rezydencji arcybiskupów przy ulicy Miodowej w Warszawie. Były one bezpieczne, aż do wybuchu Powstania Warszawskiego 1 sierpnia 1944 roku. Na temat losów tego archiwum pisał ks. W. Kwiatkowski ${ }^{1}$ oraz $\mathrm{H}$. Rybus w artykule o zniszczonych aktach arcybiskupów gnieźnieńskich i o nieznanym życiorysie Piotra Gamrata ${ }^{2}$. Bezcenne źródła zawierały nie tylko akta poszczególnych prymasów, lecz również bogatą korespondencję z cesarzami, królami, papieżami oraz innymi osobistościami Europy począwszy od XV wieku. Materiałów tych nie wykorzystał dziewiętnastowieczny badacz gnieźnieński ks. Jan Korytkowski, który pozostawił dwa monumentalne dzieła: pięciotomową biografię prymasów oraz czterotomową publikację o prałatach i kanonikach Kapituły Metropolitalnej w Gnieźnie ${ }^{3}$.

* Ks. Kazimierz Śmigiel - prof. historii; emerytowany wykładowca Uniwersytetu Kazimierza Wielkiego w Bydgoszczy, Prymasowskiego Wyższego Seminarium Duchownego w Gnieźnie, Wyższego Seminarium Duchownego w Bydgoszczy; e-mail: k.smigiel@poczta.onet.eu

ORCID 0000-0002-4567-8750

${ }^{1}$ W. Kwiatkowski, Akta prymasów z XVII i XVIII wieku w Warszawie, „Ateneum Kapłańskie”, 46 (1947) s. 508-510; tenże, Zachowane odpisy dokumentów i akt Archiwum Prymasów Polski, „Ateneum Kapłańskie”, 48 (1948) s. 384-387.

${ }^{2} \mathrm{H}$. Rybus, Kilka uwag o zniszczonych aktach arcybiskupów gnieźnieńskich i o nieznanym życiorysie Piotra Gamrata, „Archiwa Biblioteki i Muzea Kościelne”, 2 (1961) z. 1-2, s. 303-316.

${ }^{3}$ J. Korytkowski, Arcybiskupi gnieźnieńscy: prymasowie i metropolici polscy od roku 1000 aż do roku 1821 czyli do połaczenia arcybiskupstwa gnieźnieńskiego z biskupstwem poznańskim. t. 1-5, Poznań 1888-1892; tenże, Prałaci i kanonicy katedry metropolitalnej gnieźnieńskiej od roku 1000 aż do dni naszych, t. 1-4, Gniezno 1883. 
W 2018 r. autor tego artykułu opublikował obszerną monografię Prymasostwo polskie. Instytucja, prymasi, dokumenty ${ }^{4}$.

Nadal największym problemem badawczym pozostaje wyjaśnienie genezy prymasostwa polskiego, dokładne określenie czasu i okoliczności powstania tej instytucji. Dotychczasowe badania doprowadziły do powstania kilku opinii, które wywarły wpływ na rozwój licznej literaturys. Według zasłużonego kanclerza i prymasa Jana Łaskiego prymasostwo powstało w połowie XIV wieku z nadania króla Kazimierza Wielkiego i jest organicznie związane ze Statutem Wielkopolskim. Oczywiście ta opinia była nieprawdziwa, ale przez wieki funkcjonowała w świadomości prymasów i w licznych opracowaniach, zwłaszcza w pomnikach prawa polskiego. Elementy składowe tej opinii opierają się na błędnych założeniach, co jednak nie przeszkadzało w ich multiplikacji.

Piętnastowieczny świadek życia państwowego i kościelnego Jan Długosz, ojciec historyków polskich, pozostawił w spuściźnie kilka problemów badawczych. Najbardziej rozpowszechniona teoria soborowa Jana Długosza zawiera elementy mieszane i złożona jest z trzech składników: król, Sobór w Konstancji (14141418) i przywilej prymasowski, ale właśnie te elementy trudno zweryfikować, bowiem Długosz „kluczy”, co jest typowe dla tego autora. Panującym raz jest Mieszko, innym razem Bolesław Chrobry. Skoro już raz wskazało się na osobę panującego, trudno jest wyjaśnić rolę Soboru w Konstancji. Z tym problemem poradził sobie Długosz, przyjmując wtórną rolę Soboru w Konstancji, który nie ustanowił prymasostwa, lecz je odświeżył, odnowił, bo jego początki schodzą się z początkami państwa polskiego. I wreszcie słynny przywilej prymasowski, który Długosz datuje na rok 1417. Właśnie wspomniany dokument jest podstawą obchodu 600. rocznicy i roku prymasowskiego. I tu zaczyna się ciężki problem dla badaczy, z którym nie mogą oni sobie poradzić od kilkuset lat.

Wspomniany dokument jest w wysokich stopniu kontrowersyjny. Adresat tego przywileju, czyli Mikołaj Trąba nie stosował go ani podczas obrad soborowych ani tuż po jego zakończeniu.

Jedna z wersji Jana Długosza o soborowym odnowieniu tytułu i przywileju prymasowskiego nie znajduje potwierdzenia w materiałach źródłowych związanych z Soborem w Konstancji:

1. W aktach urzędowych soboru nigdy i nigdzie nie widnieje arcybiskup Mikołaj jako prymas, również na protokole ostatniej sesji soboru 22 kwietnia $1418 \mathrm{r}$.

2. Trąba nie tytułuje się prymasem $\mathrm{w}$ listach wysyłanych $\mathrm{w}$ czasie trwania soboru.

3. Przed zamknięciem obrad soborowych delegacja polska domagała się od papieża Marcina V potępienia oszczerczego pisma Falkenberga pt. Satyra na herezje i inne nikczemności Polaków oraz ich króla Jagietty. W odpowiedzi na odmowę ze strony papieża, polska delegacja doręczyła Marcinowi V apelację do przyszłego soboru na audiencji w dniu 4 maja 1418 r., która opracowana została notarialnie 1 maja przez członka delegacji polskiej, Pawła Włodkowica. Protest

\footnotetext{
${ }^{4} \mathrm{~K}$. Śmigiel, Prymasostwo polskie. Instytucja, prymasi, dokumenty, Warszawa 2018.

${ }^{5}$ Tenże, Tradycje powstania prymasostwa polskiego. Zagadnienie historiograficzne, „Kościót w Polsce. Dzieje i Kultura", 16 (2017) s. 129-148.
} 
polski był drażliwym przejawem koncyliaryzmu i dokonany został wbrew zakazowi papieskiemu wnoszenia jakiejkolwiek apelacji do soboru. Nie ulega wątpliwości, że apelacja powstała pod bacznym okiem samego Trąby, który nazwany jest tylko arcybiskupem.

4. Trąba nie jest nazwany prymasem $w$ dokumencie wystawionym 13 maja przez kancelarię papieską, w którym papież Marcin V zarządza roczne zawieszenie broni pomiędzy Polakami a Krzyżakami.

5. Korespondencja poselstwa Zakonu Krzyżackiego nie zawiera żadnej wzmianki o nowej godności Mikołaja Trąby, a wiadomo, że interesowało się ono wnikliwie poselstwem polskim.

6. Trąba wracając do kraju, zatrzymał sie w dniach 11-16 czerwca we Wrocławiu, aby podporządkować sobie jako metropolicie nowo mianowanego biskupa wrocławskiego Konrada, księcia opolskiego usiłującego wyłamać się spod zwierzchnictwa Gniezna. Źródło XV-wieczne relacjonuje nadzwyczajne wydarzenia w przyrodzie, natomiast milczy o nowej godności metropolity gnieźnieńskiego.

Musi zastanawiać, dlaczego wokół nowej godności przewodniczącego znaczącej delegacji na sobór, jest głucho w znanych przekazach źródłowych.

Momentem zwrotnym stało się spotkanie pierwszego prymasa z królem Władysławem Jagiełą 19 czerwca 1418 r. w Pobiedziskach (pomiędzy Gnieznem a Poznaniem). Od tego czasu Mikołaj Trąba i jego następcy tytułowali się prymasami. Zachowane pieczęcie Trąby nie zawierają tytułu prymasowskiego.

$\mathrm{Na}$ temat dokumentu prymasowskiego nie ma wzmianki w aktach Soboru w Konstancji ani śladu w całym zasobie archiwów kościelnych w Polsce. Trudno nawet sobie wyobrazić, aby istnienie podstawowego dokumentu Kościoła polskiego nie zostało odnotowane poza Długoszem. Wniosek jest jeden: taki dokument nigdy nie istniał, a Długosz swój domysł utrwalił jako pewnik w swoim dziele, który wykorzystywali jego liczni naśladowcy.

W 2016 r. próbowano wyjaśnić tę sprawę w rzymskich instytucjach prosząc ks. prałata Guido Mariniego, Mistrza Papieskich Ceremonii Liturgicznych, który zasugerował, aby skierować zapytanie do ks. prałata Udo Breitbacha, Podsekretarza Kongregacji ds. Biskupów. Jak dotąd, na pismo nie udzielono odpowiedzi.

Już XVI-wieczny prymas Jan Łaski zdawał sobie dobrze sprawę, że krucha jest baza źródłowa dotycząca prymasostwa i dlatego postarał się o bullę Leona X Pro eccelenti praeeminentia z lipca 1515 r. Dokument ten stał się kamieniem milowym, ale tak naprawdę poza potwierdzeniem urzędu prymasa i erekcją legata stałego legatus natus nie rozwiązał istotnych problemów. Nie został wyjaśniony zakres jurysdykcji prymasowskiej i legacji stałej oraz relacje pomiędzy tymi urzędami. Już wspomniany XIX-wieczny historyk Jan Korytkowski zauważył, że brakowało intencji i woli, aby te sprawy wyjaśnić. Zarówno Kościół polski, jak i Korona nie dążyły, ażeby wyjaśnić sformułowania bulli, że uprawnienia prymasów są ad instar (na podobieństwo) prymasa w Canterbury i innych prymasów. Potrzebna była tylko tytulatura. Wiadomo zaś, że przywileje prymasowskie i legackie w innych krajach nie były takie same i rozwojowe.

Należy zauważyć, że Długosz rozpisując się o małżeństwie Władysława Jagiełły z Elżbietą Granowską i jej koronacji dokonanej przez metropolitę lwow- 
skiego Jana Rzeszowskiego w powiązaniu z prymasostwem Mikołaja Trąby, starannie przemilczał relacje prawne pomiędzy obu metropolitami (gnieźnieńskim i lwowskim).

Znany jest początek stosowania przez metropolitów gnieźnieńskich prawa prymasowskiego: 1449 r. - aktywność sądownicza i 1485 r. - aktywność synodalna. Wszystko wskazuje na to, że prawo prymasowskie podlegało ewolucji i stąd wynika ważny postulat badawczy: stosowanie jurysdykcji sądowniczej i administracyjnej przez prymasów. Może więcej światła rzucą odkryte niedawno w katedrze gnieźnieńskiej materiały źródłowe z drugiej połowy XV wieku. A w ogóle ten problem wymaga gruntownego wyjaśnienia.

Od przełomu XV/XVI w. prymasi byli ważnym czynnikiem w rozwoju parlamentaryzmu polskiego. „Prymas senatu mojego” - jak wyraził się Zygmunt I w liście do papieża Pawła III, prosząc o prowizję na metropolię gnieźnieńską dla swego kandydata Andrzeja Krzyckiego. Najnowsze badania A. Sucheni-Grabowskiej przynoszą ważne stwierdzenie, że prymasi zajmowali nie tylko pierwsze krzesło w senacie, ale rzeczywiście nim kierowali przewodnicząc jego obradom. Starsze opracowania przypisywały tę rolę królowi, co jednak nie mieści się w standardach prestiżu monarchy. Wspomniane stwierdzenie potwierdza tezę, że to właśnie król potrzebował na stanowisku prymasa zarówno sojusznika politycznego, jak i zaprawionego w służbie państwa urzędnika. Nieusuwalność dostojników kościelnych była dodatkowym atutem ${ }^{6}$.

Prymasi brali udział w sporach o ustrój państwa. Np. Jan Łaski opowiadał się za demokracją szlachecką i ograniczeniem hegemonii możnowładztwa.

Autorzy unikają wspomnianej problematyki. Wkład prymasów do polskiego życia parlamentarnego jest totalnie zaniedbanym aspektem ich działalności. Bowiem prymasi zabierając głos jako pierwsi mówcy z góry nastrajali całą debatę.

Należy zwrócić jeszcze uwagę na pomysł badawczy związany z działalnością fundacyjną prymasów. Pytanie brzmi: jak krojono wielki bochen „chleba” prymasów na realizację celów fundacyjnych w skali całego kraju. Znane są przyczynki, ale stale brak całości. Na zakończenie przypomnę słowa prymasa Krzysztofa Szembeka w liście do podkanclerzego J. Małachowskiego z dnia 12 października $1741 \mathrm{r}$ :

Praeeminentia w żadnem królestwie europejskim niepraktykowana i niesłychana rzecz, ażeby miał kto z duchownych prerogatywy, jak ma prymas pol$\mathrm{ski}^{7}$.

Trudno odmawiać prymasowi kompetencji, ale skoro taka była rzeczywistość, właśnie w tym kierunku powinien zmierzać rozwój badań nad prymasostwem polskim.

${ }^{6}$ A. Sucheni-Grabowska, Prymasi XVI stulecia w polskim systemie parlamentarnym, w: Prymasi i prymasostwo $w$ dziejach państwa i narodu polskiego, red. W.J. Wysocki, Warszawa 2002, s. 19-21.

${ }^{7}$ M. Skibiński, Europa a Polska $w$ dobie wojny o sukcesye austryacka $w$ latach 1740-1745, t. 2. Kraków 1912, s. 672. 


\section{BIBLIOGRAFIA}

Korytkowski J., Arcybiskupi gnieźnieńscy: prymasowie i metropolici polscy od roku 1000 aż do roku 1821 czyli do połaczenia arcybiskupstwa gnieźnieńskiego z biskupstwem poznańskim.t. 1-5, Poznań 1888-1892;

Korytkowski J., Prałaci i kanonicy katedry metropolitalnej gnieźnieńskiej od roku 1000 aż do dni naszych, t. 1-4, Gniezno 1883.

Kwiatkowski W., Akta prymasów z XVII i XVIII wieku w Warszawie, „Ateneum Kapłańskie", 46 (1947) s. 508-510;

Kwiatkowski W., Zachowane odpisy dokumentów i akt Archiwum Prymasów Polski, „Ateneum Kapłańskie", 48 (1948) s. 384-387.

Rybus H., Kilka uwag o zniszczonych aktach arcybiskupów gnieźnieńskich i o nieznanym życiorysie Piotra Gamrata, „Archiwa Biblioteki i Muzea Kościelne”, 2 (1961) z. 1-2, s. 303-316.

Skibiński M., Europa a Polska w dobie wojny o sukcesyę austryacka w latach 1740-1745, t. 2. Kraków 1912, s. 672.

Sucheni-Grabowska A., Prymasi XVI stulecia $w$ polskim systemie parlamentarnym, w: Prymasi i prymasostwo w dziejach państwa i narodu polskiego, red. W.J. Wysocki, Warszawa 2002, s. 19-21.

Śmigiel K., Tradycje powstania prymasostwa polskiego. Zagadnienie historiograficzne, „Kościół w Polsce. Dzieje i Kultura”, 16 (2017) s. 129-148.

Śmigiel K., Prymasostwo polskie. Instytucja, prymasi, dokumenty, Warszawa 2018.

\section{Z PROBLEMATYKI BADAWCZEJ DOTYCZĄCEJ DZIEJÓW PRYMASOSTWA POLSKIEGO}

\section{Streszczenie}

Badania dziejów prymasostwo jest utrudnione gdyż nie zachowało się archiwum prymasów wytworzone w czasach od XV-XVIII wieku, a przechowywane w Łowiczu. Obejmowało ono 163 tomów akt. W połowie XIX wieku zainteresował się nim arcybiskup warszawski Zygmunt Szczęsny Feliński i polecił je przewieźć do rezydencji arcybiskupów przy ulicy Miodowej. Archiwalia zostały spalone przez Niemców podczas Powstania Warszawskiego. Bezcenne źródła zawierały nie tylko akta poszczególnych prymasów, lecz również bogatą korespondencję z cesarzami, królami, papieżami oraz innymi osobistościami Europy począwszy od XV wieku. Materiałów tych nie wykorzystał dziewiętnastowieczny badacz gnieźnieński ks. Jan Korytkowski, który pozostawił dwa monumentalne dzieła: pięciotomową biografię prymasów oraz czterotomową publikację o prałatach i kanonikach Kapituły Metropolitalnej w Gnieźnie.

Nadal największym problemem badawczym pozostaje wyjaśnienie genezy prymasostwa polskiego, dokładne określenie czasu i okoliczności powstania tej instytucji.

Początek prymasostwa w Poslce związany jest z obradami Soboru w Konstancji (1414-1418) i uczestnictwa na nim abpa Mikołaja Trąby. W 1417 r. uzyskał on według J. Długosza przywilej prymasowski dla siebie i następców.

Po raz pierwszy tytułu prymasa użył abp gnieźnieński Mikołaj Trąba, podczas spotkania z królem Władysławem Jagiełą 19 czerwca 1418 r. w Pobiedziskach k. Gniezna. Od tego czasu i jego następcy tytułowali się prymasami. Zachowane pieczęcie Trąby nie 
zawierają jednak tytułu prymasowskiego. Już XVI-wieczny prymas Jan Łaski zdawał sobie dobrze sprawę, że krucha jest baza źródłowa dotycząca prymasostwa i dlatego postarał się o bullę Leona X Pro eccelenti praeeminentia z lipca 1515 r. Dokument ten poza potwierdzeniem urzędu prymasa i erekcją legata stałego legatus natus nie rozwiązał jednak istotnych problemów.

Od przełomu XV/XVI w. prymasi byli ważnym czynnikiem w rozwoju parlamentaryzmu polskiego. Prymasi brali udział w sporach o ustrój państwa. Np. Jan Łaski opowiadał się za demokracją szlachecką i ograniczeniem hegemonii możnowładztwa. W czasach bezkrólewia prymasi pełnili rolę Interrexa, posiadając duża władze polityczną.

Słowa kluczowe: prymas Polski; Sobór w Konstancji; Mikołaj Trąba; arcybiskup gnieźnieński; Interrex

\section{RESEARCH ON THE HISTORY OF THE POLISH PRIMACY}

\section{Summary}

The study of the history of primacy is hindered by the fact that primates' archive created in the 15th-18th centuries (held in Lowicz) has not survived. It encompassed 163 volumes of records. In the mid-19th century, the Archbishop of Warsaw, Zygmunt Szczęsny Feliński, became interested in this archive and ordered to transfer it to the archbishops' residence in Miodowa Street. The archival materials were burnt by the Germans during the Warsaw Uprising. These invaluable sources included not only primates' records but also the rich correspondence with emperors, kings, popes and other eminent figures of Europe from the 15th century onwards. These materials were not used by the 19th-century researcher from Gniezno, Rev. Jan Korytkowski, who wrote two voluminous works: the five-volume biography of primates and the four-volume publication about prelates and canons of the Metropolitan Chapter in Gniezno.

Currently, the greatest research problem is to explain the genesis of the Polish primacy as well as determine the exact time and circumstances of emerging this institution.

The beginning of the primacy in Poland is connected with the Council of Constance (1414-1418) and Archbishop Mikołaj Trąba's participation in it. In 1417, he received, according to J. Długosz, the primate privilege for himself and his successors.

The Archbishop of Gniezno, Mikołaj Trąba, used the title 'primate', for the first time, during his meeting with King Władysław Jagiełło on 19 June 1418 in Pobiedziska near Gniezno. From that moment onwards, his successors used the titles of primate. The surviving stamps of Trąba, however, does not have this title. The 16th-century Primate Jan Łaski was aware of the fact that source basis for the title of primate was not plausible and that was why he did his best to obtain Leo X's bull Pro Eccelenti Praeeminentia of July 1515. This document, however, apart from confirming the office of primate and introducing a permanent legate 'legatus natus' did not solve serious problems.

From the turn of the 16th century onwards, primates played an important role in the development of the Polish parliamentary system. Primates took part in disputes over the form of the government. For example, Jan Łaski was for the 'nobles' democracy and limiting the hegemony of the magnates. During the period of an interregnum, primates served as interrex, wielding considerable political power.

Keywords: the primate of Poland; the Council of Constance; Mikołaj Trąba; the Archbishop of Gniezno; interrex 